\title{
Pengaruh Teknik Relaksasi Otot Progresif Terhadap Tingkat Stres Kerja Pada Staf Puskesmas Banyuputih Situbondo
}

\author{
Finanin Nur Indana ${ }^{1}$ \\ Risda Ayu Tsabitah ${ }^{2}$ \\ 1,2, Fakultas Ilmu Sosial dan Humaniora, Universitas Ibrahimy Situbondo \\ Email: finanin490@gmail.com
}

\begin{abstract}
Job Stress Caused By Work Pressure, Lack Of Managerial Support, And The Risk Of Violence And Bullying. Stress Due To Work Experienced By Workers If Not Immediately Addressed Will Have An Impact Both For Themselves And The Company. This Study Aims To Assess The Effect Of Progressive Muscle Relaxation In Reducing Work Stress On public healts center Banyuputih Staff. The Study Design Was Quasi Experimental Pre-Post Test Without Control Group With 35 Samples By Purposive Sampling. The Results Of The Study Using The Wilcoxon Signed Ranks Test Statistical Test Obtained P-Value Of 0,000 (P <0.05). This Means That There Was The Effect Of Progressive Muscle Relaxation To Reduce Work Stress. Research Recommendations That Progressive Muscle Relaxation Be Applied By Workers During The Work Process Be Evidence Based Practice For Occupational Health Nurses In Overcoming Work Stress On Workers.
\end{abstract}

Keyword: Progressive Muscle Relaxation, Stress, Worker

\begin{abstract}
Abstrak
Stress akibat kerja disebabkan oleh tekanan kerja, kurangnya dukungan manajerial, serta risiko kekerasan dan bullying. Stress akibat kerja yang dialami oleh pekerja jika tidak segera diatasi akan memberikan dampak baik bagi diri sendiri maupun perusahaan. Penelitian ini bertujuan untuk menilai pengaruh relaksasi otot progresif dalam menurunkan stres kerja pada staf puskesmas Banyuputih. Desain penelitian quasi eksperiment pre-post test without control group dengan 35 sampel secara purposive sampling. Hasil penelitian menggunakan uji statistik Wilcoxon Signed Ranks Test didapatkan nilai $p$-value 0,000 ( $p<0,05)$. Hal ini berarti terdapat pengaruh relaksasi otot progresif untuk menurunkan stres kerja. Rekomendasi penelitian bahwa relaksasi otot progresif diterapkan pekerja selama proses kerja. dan menjadi evidence based practice bagi perawat kesehatan kerja dalam mengatasi stress kerja pada pekerja.
\end{abstract}

Kata kunci: relaksasi otot progresif, stres, pekerja

Copyright (C) 2021. Finanin Nur Indana, Risda Ayu Tsabitah. 


\section{Pendahuluan}

Stress akibat kerja yang dialami oleh pekerja di Great Britain pada tahun 20112012 tercatat sebanyak 428.000 atau 40\% dari total pekerja, dan jumlah tersebut merupakan kasus baru. Stress akibat kerja disebabkan oleh tekanan kerja, kurangnya dukungan manajerial, serta risiko kekerasan dan bullying (HSE, 2013).

Berdasarkan American Psychological Statistics (2014) menyatakan stress akibat kerja di Amerika Serikat pada tahun 2013-2014 sebanyak 33\% pekerja yang hidup dengan stress berat, 48\% mengatakan merasa lebih stress selama lima tahun ini, dan sebanyak $48 \%$ yang mengatakan sulit tidur atau terbangun saat tidur disebabkan stress.

Penelitian yang dilakukan oleh World Health Organization (WHO) tahun 1999 dalam Kemenkes (2010) menyatakan bahwa penyakit akibat kerja khususnya gangguan jiwa sebanyak 10-30\% kasus. Dewi (2011) juga menjelaskan bahwa pekerja di Indonesia juga mengalami masalah kesehatan jiwa sebesar 15-30\%. Faktor risiko stres kerja dapat dipengaruhi dari lingkungan kerja (bising, tata ruang, suhu, pencahayaan), beban kerja, peran individu dalam organisasi dan faktor individu itu sendiri. Seseorang dikatakan mengalami stress apabila mengalami kecemasan, gangguan tidur, mudah marah, sulit konsentrasi, sedih, keringat dingin, kelelahan kronik, dan psikosomatik.

Selye (1976) dalam Potter dan Perry (2005) menjelaskan bahwa stress adalah segala situasi dimana tuntutan non spesifik mengharuskan seseorang individu untuk berespon atau melakukan tindakan. Gibson (2000) juga mengemukakan bahwa stress kerja merupakan proses psikologis yang terjadi sebagai konsekuensi dari perilaku atau kejadian - kejadian pada lingkungan kerja dan menimbulkan akibat - akibat khusus secara psikologis, fisiologis, dan perilaku individu. Stress akibat kerja yang dialami oleh pekerja jika tidak segera diatasi akan memberikan dampak baik bagi diri sendiri maupun perusahaan.

Dampak bagi pekerja adalah mempengaruhi aspek psikologis, perilaku, kognitif, dan fisiologis. Pengaruh psikologis berupa kegelisahan, agresi, kelesuan, kebosanan, depresi, kelelahan, kekecewaan, kehilangan kesabaran, harga diri yang rendah. Pengaruh perilaku, berupa peningkatan konsumsi alkohol, tidak nafsu makan atau makan berlebihan, penyalahgunaan obat-obatan, menurunnya semangat untuk berolahraga yang berakibat timbulnya beberapa penyakit.

Pada saat stres juga terjadi peningkatan intensitas kecelakaan, baik di rumah, di tempat kerja atau di jalan. Pengaruh kognitif, yaitu ketidakmampuan mengambil kcputusan, kurangnya konsentrasi, dan peka terhadap ancaman. Pengaruh fisiologis, yaitu menyebabkan gangguan pada kesehatan fisik yang berupa penyakit yang sudah diderita sebelumnya, atau memicu timbulnya penyakit tertentu. Dampak bagi perusahaan antara lain terjadinya kekacauan, hambatan baik dalam manajcmen maupun operasional kerja, mengganggu kenormalan aktivitas kerja, menurunkan tingkat produktivitas, menurunkan pemasukan dan keuntungan perusahaan. 
UU No.13 tahun 2003 tentang Ketenagakerjaan terutama pasal 86 dan 87 mengatakan bahwa setiap pekerja berhak memperoleh keselamatan dan kesehatan kerja, untuk mewujudkan produktivitas yang optimal perlu upaya keselamatan dan kesehatan kerja, dan setiap perusahaan wajib melaksanakan sistim manajemen upaya keselamatan dan kesehatan kerja yang terintegrasi dengan sistim manajemen perusahaan. Stress akibat kerja dapat diatasi dengan upaya pencegahan dan perawatan.

Manajemen stres dengan teknik relaksasi merupakan salah satu teknik pengelolaan diri yang didasarkan pada cara kerja sistem saraf simpatis dan parasimpatis. Selain itu juga, ketika otot-otot sudah dirilekskan maka akan menormalkan kembali fungsi-fungsi organ tubuh. Setelah seseorang melakukan relaksasi dapat membantu tubuhnya menjadi rileks, dengan demikian dapat memperbaiki berbagai aspek kesehatan fisik.

Stress kerja bisa diatasi dengan beberapa tindakan seperti olahraga, relaksasi, peregangan, dan manajemen stress. Salah satu teknik relaksasi yang dapat dilakukan adalah relaksasi otot progresif. Resti (2014) menjelaskan dalam hasil penelitiannya bahwa terjadi penurunan tingkat stress pada pasien asma setelah diberikan 6 (enam) kali sesi latihan relaksasi otot progresif.

Penelitian ini menggunakan metode self report dan wawancara dalam proses pengumpulan datanya. Penelitian serupa dilakukan oleh Lestari dan Yuswiyanti (2014) yang menunjukkan hasil bahwa ada pengaruh relaksasi otot progresif terhadap penurunan tingkat kecemasan pada pasien pre operasi.

Relaksasi otot progresif merupakan teknik manajemen stres cukup sering digunakan untuk mereduksi stres. Relaksasi otot progresif menurut Jacobson adalah suatu keterampilan yang dapat dipelajari dan digunakan untuk mengurangi atau menghilangkan ketegangan dan mengalami rasa nyaman tanpa tergantung pada hal/subjek diluar dirinya.

Relaksasi otot progresif ini digunakan untuk melawan rasa cemas, stres, atau tegang. Dengan menegangkan dan melemaskan beberapa kelompok otot dan membedakan sensasi tegang dan rileks, seseorang bisa menghilangkan kontraksi otot dan mengalami rasa rileks (Soewondo, 2009).

Hal ini dikarenakan relaksasi otot progresif merupakan jenis relaksasi termurah, mudah untuk dilakukan secara mandiri. Tujuan pokok teknik relaksasi adalah untuk menahan terbentuknya respon stres terutama dalam sistem saraf dan hormon. Pada akhirnya teknik relaksasi dapat membantu mencegah atau meminimalkan gejala fisik akibat stres ketika tubuh bekerja berlebihan dalam menyelesaikan masalah sehari-hari (National safety council, 2004).

\section{Metode}

Metode yang dilakukan dalam penelitian ini adalah quasi experiment yang bertujuan untuk mengetahui apakah relaksasi otot progresif mempunyai pengaruh untuk menurunkan stress kerja pada staf Pusesmas Banyuputih Situbondo. Rancangan penelitian yang digunakan adalah pretest-posttest without control design, dimana 
responden diukur stress kerja sebelum dan sesudah dilakukan intervensi yaitu relaksasi otot progresif. Lokasi penelitian adalah di ruang kelas Pusesmas Banyuputih Situbondo dengan melibatkan responden sebanyak 35 orang yang sesuai kriteria penelitian (purpossive sampling).

Pengumpulan data dilakukan dengan instrument DASS (Depressive Anxiety Stress Scale) khususnya 14 poin mengenai stress kerja. Intervensi relaksasi otot progresif dilakukan dengan 14 gerakan dasar dan dilaksanakan dalam 6 (enam) sesi latihan.

\section{Hasil}

1. Karakteristik Responden

\section{Tabel 1}

\begin{tabular}{|c|l|c|c|}
\hline No. & Karakteristik Responden & $\begin{array}{c}\text { Frekuens } \\
\text { i }\end{array}$ & $\begin{array}{c}\text { Prosentase } \\
\text { (\%) }\end{array}$ \\
\hline $\mathbf{1 .}$ & $\begin{array}{l}\text { Umur } \\
\text { - 20-29 Tahun }\end{array}$ & 16 & $45,7 \%$ \\
\hline & - 30-39 Tahun & 19 & $54,3 \%$ \\
\hline & Jumlah & $\mathbf{3 5}$ & $\mathbf{1 0 0 \%}$ \\
\hline $\mathbf{2 .}$ & $\begin{array}{l}\text { Jenis Kelamin } \\
\text { - Laki-laki } \\
\text { - Perempuan }\end{array}$ & 7 & $20,0 \%$ \\
\hline & Jumlah & $\mathbf{3 5}$ & $80,0 \%$ \\
\hline
\end{tabular}

Berdasarkan tabel 1 diatas dapat disimpulkan dari hasil penelitian diketahui bahwa usia responden yang berkisar 20-29 tahun sebanyak 16 responden $(45,7 \%)$ dan umur 30-39 tahun sebanyak 19 responden (54,3\%). Berdasarkan karekteristik jenis kelamin mayoritas perempuan yaitu sebanyak 28 responden $(80,0 \%)$.

2. Gambaran Tingkat Stres Sebelum Intervensi

\begin{tabular}{|c|c|c|}
\hline \multirow{2}{*}{ Tingkat Stres } & \multicolumn{2}{|c|}{ Sebelum (Pre test) } \\
\hline & $\begin{array}{c}\text { Frekuens } \\
\text { i }\end{array}$ & $(\%)$ \\
\hline Normal & 0 & $0 \%$ \\
\hline Ringan & 21 & $60,0 \%$ \\
\hline Sedang & 14 & $40,0 \%$ \\
\hline Berat & 0 & $0 \%$ \\
\hline Sangat Berat & 0 & $0 \%$ \\
\hline Jumlah & 35 & $100 \%$ \\
\hline
\end{tabular}




\begin{tabular}{|c|c|c|c|l|}
\hline \multirow{2}{*}{ Stress } & \multicolumn{3}{|c|}{ Kolmogorov-Smirnov } & \multirow{2}{*}{ Kesimpulan } \\
\cline { 2 - 4 } & $\begin{array}{c}\text { Statisti } \\
\mathbf{k}\end{array}$ & $\mathbf{d f}$ & $\begin{array}{c}\text { Sig. } \\
\mathbf{( p} \\
\text { value })\end{array}$ & $\begin{array}{l}\text { Data berdistribusi } \\
\text { tidak normal }\end{array}$ \\
\hline Sebelum & 0,221 & 35 & 0,000 & $\begin{array}{l}\text { Data berdistribusi } \\
\text { tidak normal }\end{array}$ \\
\hline Sesudah & 0,171 & 35 & 0.011 & \\
\hline
\end{tabular}

Berdasarkan tabel diatas dapat diketahui bahwa distribusi frekuensi tingkat stres dalam bekerja sebelum diberikan intervensi relaksasi otot sebagian besar tergolong stres ringan yaitu sebanyak 21 responden $(60,0 \%)$, sedangkan sebagian kecil yaitu tergolong stress sedang yaitu sebanyak 14 responden $(40,0 \%)$.

3. Gambaran Tingkat Stres Setelah Intervensi

\begin{tabular}{|c|c|c|}
\hline \multirow{2}{*}{ Tingkat Stres } & \multicolumn{2}{|c|}{ Setelah (Post test) } \\
\hline & $\begin{array}{c}\text { Frekuens } \\
\text { i }\end{array}$ & $\begin{array}{c}\text { Presentase } \\
(\%)\end{array}$ \\
\hline Normal & 20 & $57,1 \%$ \\
\hline Ringan & 12 & $34,3 \%$ \\
\hline Sedang & 3 & $8,6 \%$ \\
\hline Berat & 0 & $0 \%$ \\
\hline Sangat Berat & 0 & $0 \%$ \\
\hline Jumlah & 35 & $100 \%$ \\
\hline
\end{tabular}

Berdasarkan tabel diatas dapat diketahui bahwa distribusi frekuensi tingkat stres dalam bekerja setelah dilakukan intervensi relaksasi otot sebagian besar tergolong normal yaitu sebanyak 20 responden $(57,1 \%)$, pada golongan stres ringan sebanyak 12 responden $(34,3 \%)$ dan sebagian kecil yang tergolong stres sedang yaitu sekitar 3 responden $(8,6 \%)$.

4. Uji Normalitas Data

Dengan demikian hasil pada tabel diatas diperoleh nilai p-value sebelum dilakukan terapi relaksasi otot yaitu 0.000 dan nilai p-value setelah dilakukan intervensi terapi relaksasi otot yaitu 0,011.

Kedua data mempunyai hasil nilai p-value $<0,05$ maka dapat disimpulkan bahwa data berdistribusi tidak normal $(\mathrm{p}<0,05)$. Dan pada penelitian ini secara bivariat mengunakan uji analisisnya adalah uji analisis Wilcoxon Signed Ranks Test.

5. Hasil Uji Wilcoxon Signed Ranks Test. 


\begin{tabular}{|c|c|c|c|c|c|c|c|c|}
\hline Stress & $\mathbf{n}$ & Mean & SD & $\begin{array}{c}\text { Negative } \\
\text { Ranks }\end{array}$ & $\begin{array}{c}\text { Positive } \\
\text { Ranks }\end{array}$ & Ties & Z hitung & P value \\
\hline Pre & $\begin{array}{l}3 \\
5\end{array}$ & $\begin{array}{c}18,6 \\
9\end{array}$ & 2,220 & \multirow{2}{*}{35} & \multirow{2}{*}{0} & \multirow{2}{*}{0} & \multirow{2}{*}{$-5,186$} & \multirow{2}{*}{0,000} \\
\hline Post & $\begin{array}{l}3 \\
5\end{array}$ & $\begin{array}{l}14,3 \\
7\end{array}$ & 2,474 & & & & & \\
\hline
\end{tabular}

Berdasarkan hasil dari tabel diatas bahwa terdapat nilai mean sebelum dilakukan terapi relaksasi otot adalah 18,69, dimana hasil mean lebih besar dari pada nilai mean sesudah dilakukan terapi relaksasi otot adalah 14,37. Dan pada standart deviasi sebelum diberikan terapi relaksasi otot adalah 2,220 dan sesudah dilakukan terapi relaksasi otot yaitu 2,474.

Terdapat 35 responden dengan skor stres sesudah < dari skor sebelum terapi relaksasi otot progresif (Negative Ranks) yang menunjukan adanya penurunan dari nilai pretest ke nilai posttest. Dan terdapat 0 responden dengan skor stres sebelum > dari skor stress sesudah terapi relaksasi otot progresif (Positive Ranks) yang menunjukan tidak ada peningkatan dari nilai pretest ke nilai posttest. Serta terdapat kesamaan (Ties) nilai pretest dan posttest yaitu 0 responden.

Data hasil statistik Wilcoxon Signed Ranks Test didapatkan nilai p-value 0,000 $(\mathrm{p}<0,05)$. Maka Ha diterima yang artinya bahwa ada pengaruh yang signifikan antara tingkat stres sebelum dan sesudah terapi relaksasi otot pada responden.

\section{Pembahasan}

Hasil penelitian ini sejalan dengan penelitian Livana, Daulima, Mustikasari (2018) yang menyatakan bahwa relaksasi otot progresif sangat efektif menurunkan stress keluarga yang merawat pasien gangguan jiwa disbanding kelompok yang tidak mendapatkan perlakuan. Penelitian tersebut melibatkan 48 kelompok intervensi dan 48 kelompok kontrol.

Supriati, Keliat, dan Nuraini (2010) menyatakan bahwa pelaksanaan terapi relaksasi otot progresif yang dilakukan selama 4 hari pada pasien gangguan fisik menunjukkan ada penurunan tingkat ansietas setelah pemberian terapi relaksasi otot progresif. Hashim dan Hanafi (2011) menunjukkan bahwa relaksasi otot progresif menginduksi respons suasana hati dalam mengatasi kebingungan, depresi, dan kelelahan. Oktavianis (2010) menyatakan bahwa relaksasi otot pro-gresif juga dapat menurunkan tingkat stres biologis pada pengasuh lanjut usia.

Keberhasilan terapi relaksasi otot progresif pada penelitian ini adalah peneliti melakukan relaksasi dalam 6 waktu berturut-turut. Pada sesi pertama atau hari pertama, peneliti mempraktekkan terlebih dahulu gerakan yang akan dilatih, kemudian responden diminta untuk mengulang gerakan yang sudah dilatih, kemudian ketika responden mampu mempraktekan kembali gerakan yang sudah dilatih tersebut, 
peneliti memberikan umpan balik berupa pujian kepada responden untuk menguatkan kemampuan responden melaksanakan terapi relaksasi otot progresif.

Pada hari-hari selanjutnya responden bersama-sama melakukan relaksasi dengan tetap dipandu oleh tim peneliti. Pelaksanaan relaksasi juga diiringi musik instrumental yang menenangkan sehingga membantu responden untuk rileks dan menurunkan stress kerja. Pelaksanaa terapi relaksasi ini mendukung pendapat Richmond (2013) yang menyatakan relaksasi otot progresif merupakan metode relaksasi yang paling sederhana dan mudah dipelajari untuk merilekskan otot tubuh sehingga mampu mengurangi stres.

Peneliti berpendapat bahwa latihan relaksasi otot progresif secara rutin mampu menurunkan tingkat stres dibandingkan dengan sebelum melakukan tindakan terapi tersebut. Keberhasilan terapi relaksasi otot progresif pada penelitian ini disebabkan komitmen responden yang bersedia melakukan terapi relaksasi otot progresif secara rutin selama enam hari secara berturut-turut yang difokuskan pada setiap sesi.

Penelitian juga dilakukan dengan posisi duduk yang nyaman, dengan sandaran punggung, tanpa meja, serta tidak membawa barang-barang seperti buku, kertas, dan telpon genggam. Hal ini dilakukan untuk merilekskan otot-otot dari ketegangan yang mungkin terjadi selama proses bekerja. Waktu pelaksanaan pun disesuaikan dengan jam kerja yaitu pukul 11 dan 16, dimana sudah terjadi proses bekerja sebelum dilakukan relaksasi.

\section{Kesimpulan}

Ada perbedaan yang bermakna antara tingkat stres sebelum dan setelah dilakukan intervensi teknik relaksasi otot profresif. Hasil penelitian ini diharapkan menjadi evidence based practice bagi perawat kesehatan kerja dalam mengatasi stress kerja pada pekerja.

\section{Referensi}

Allender, J.A., Spradley, B. W (2010). Community health nursing. Promotion and protection the public's health. (6 $6^{\text {th }}$ edition). USA. Lippincott Williams \& Wikins

Dewi. (2011).Kenali Tanda - tanda Stress. http://kerjasejahtera.blogspot.com/2011/08/kenali-tanda-stres-di-tempatkerja.htmlhttp://kerjasejahtera.blogspot.com/2011/08/kenali-tanda-stres-ditempat- kerja.html.

Maruli, Aditya. (2013). Jumlah Angkatan Kerja 121,2 juta. http://www.antaranews.com/berita/373306/jumlah-angkatan-kerja-1212-juta.

Potter, P.A \& Perry, A.G. (2005). Fundamentals of Nursing : concepts, process, practice.

Mosby Year Book Inc. 
Lestari KP; Yuswiyanti A. (2014). Pengaruh Relaksasi Otot Progresif terhadap Penurunan Tingkat Kecemasan pada Pasien Pre Operasi di Ruang Wijaya Kusuma RSUD DR. Soeprapto Cepu. Jurnal Keperawatan Maternitas Vol.3, No.1,

Resti IB. (2014). Teknik Relaksasi Otot Progresif untuk Mengurangi Stres pada Penderita Asma. Jurnal Ilmiah Psikologi Terpan Vol 02, No.1

Livana, Daulima, Mustikasari. (2018). Relaksasi Otot Progresif Menurunkan Stres Keluarga Yang Merawat Pasien Gangguan Jiwa. Jurnal Keperawatan Indonesia, Vol 21, No.1, hal 51-59. pISSN: 1410.-4490, eISSN: 2354-9203

Oktavianis, D. (2010). Efektivitas relaksasi otot progresif untuk menurunkan tingkat stres padapengasuh lanjut usia di Panti Werdha X (Tesis, tidak dipublikasikan). Fakultas Psikologi Universitas Airlangga, Surabaya.

Hashim, H.A., \& Hanafi, A.Y.H. (2011). The effects of progressive muscle relaxation and autogenic relaxation on young soccer players' moodstates. Asian Journal of Sports Medicine, 2 (2), 99-105.

Richmond, R.L. (2013). A guide to psychology and its practice: Progressive muscle relaxation. Diperoleh dari http://www.guidetopsychology.com/pmr.htm

Supriati, L., Keliat, B.A., \& Nuraini, T. (2010). Pengaruh terapi tought stopping dan progressive muscle relaxation terhadap ansie-tas pada pasien dengan gangguan fisik di RSUD Dr. Soewondo Madiun (Tesis, tidak dipublikasikan). Fakultas Ilmu Keperawatan Universitas Indonesia, Depok - Jawa Barat 